\title{
OPTIMAL SAVINGS FOR RETIREMENT: THE ROLE OF INDIVIDUAL ACCOUNTS
}

\author{
Julia Le BLANC \\ Deutsche Bundesbank \\ Almuth SCHOlL \\ University of Konstanz
}

\begin{abstract}
We employ a life-cycle model with income risk to analyze how tax-deferred individual accounts affect households' savings for retirement. We consider voluntary accounts as opposed to mandatory accounts with minimum contribution rates. We contrast add-on accounts with carve-out accounts that partly replace social security contributions.

Quantitative results suggest that making add-on accounts mandatory has adverse welfare effects across income groups. Carve-out accounts generate positive welfare effects across all income groups, but gains are lower for low income earners. Default investment rules in individual accounts have a modest impact on welfare.
\end{abstract}

Keywords: Individual Accounts, Retirement, Household Portfolio Choice, Saving over the Life Cycle

\section{INTRODUCTION}

In many countries tax-deferred individual accounts have become an increasingly important component of the social security system. Around the world, different pension systems feature different types of defined contribution plans. Whereas in the United States IRAs or 401(k) plans are voluntary, other countries such as Sweden, Denmark, and Australia recently introduced individual accounts with compulsory contributions that coexist with the unfunded public pension system. In contrast, in the United Kingdom and Japan, households can decide whether to contribute to the public retirement system or "contract out" into approved personal pension plans that fully or partially replace social security contributions. Since the President's Commission suggested in 2001 that mandatory individual accounts be 
included in the social security system, there has been an ongoing policy debate on the role of individual accounts in the U.S. pension system. ${ }^{1}$

This paper employs a life-cycle model with exogenous stochastic labor income calibrated to the United States to analyze how different types of tax-deferred individual accounts affect households' consumption, savings, and portfolio allocation decisions, as well as welfare. Our life-cycle model of portfolio choice builds on Dammon et al. (2004) and Gomes et al. (2009) and assumes that households can save in a taxable as well as an illiquid, tax-deferred account. In line with the literature on limited stock holding, in order to hold risky assets in the taxable account, households need to pay a fixed stock market entry fee. In contrast, investing in stocks is costless in the tax-deferred account.

We follow the categorization of Turner (2006) and consider three different types of individual accounts. First, as in Gomes et al. (2009), households can save voluntarily in the individual account. Second, households make compulsory minimum contributions to the individual account on top of their contributions to the public defined-benefit retirement system. Third, households carve out into mandatory individual accounts that replace part of the public social security system. In this scenario, households get a rebate on their contributions to the public pension system but are required to invest that amount in the funded individual account.

Our quantitative results show that households save in voluntary individual accounts for two reasons. First, taxation is deferred, i.e., taxes are paid upon withdrawal, and, second, the retirement account provides costless access to risky assets yielding a risk premium. On the other hand, retirement accounts are illiquid, and in our model households cannot withdraw funds until retirement age. In line with Pries (2007) and Gomes et al. (2009), our simulation results show that early in life households save little in the illiquid account, but from age 35 the contributions to the individual account start to rise, so that retirement wealth follows a hump shape over the life cycle.

If households are required to hold mandatory add-on accounts with a compulsory minimum contribution rate, they are forced to invest more for retirement in younger years when they would rather consume than save. Making retirement savings mandatory that households would voluntarily undertake at later stages in life generates welfare losses of roughly $1.5 \%$ of certainty-equivalent consumption. Comparing add-on and carve-out accounts reveals that the latter generate higher savings in the individual account, as well as in the liquid taxable account, because of the positive income effect of the rebate on the social security contributions. In retirement, when households have lower income from the public pension system, they use their private retirement wealth to compensate for the loss. Our analysis suggests that carve-out accounts have positive welfare effects across income groups because of the benefits of converting social security contributions into individually managed accounts with optimally chosen risky portfolio shares. However, welfare gains are lower for low income earners because they face limited benefits from tax deferral. 
In view of the recent financial turmoil, it has become particularly important to understand the influence of stock market crashes on households' retirement savings, their portfolio choices, and the role of individual accounts. ${ }^{2}$ Household wealth data suggest that households have substantially reduced their stock market exposure since the early 2000s. To capture the effects of a financial downturn, we incorporate the risk of losing retirement benefits because of a financial market downturn and analyze the impact of disaster expectations on optimal retirement savings in individual accounts. Following Alan (2012), we introduce disaster expectations by assuming that households face a small probability of experiencing a stock market crash in each period when they update their expectations. ${ }^{3} \mathrm{We}$ use the estimated disaster probabilities and stock market drops for the United States by Barro and Ursua (2008) and analyze the effects of the perceived risk of a financial market downturn on retirement savings considering the different types of individual accounts. Our quantitative findings suggest that the perceived risk of a financial market downturn affects optimal savings and portfolio choices substantially: Households strongly reduce their stock market exposure in the taxable liquid account and reduce their contributions to the illiquid individual account.

The worldwide trend toward defined contribution plans for retirement has also raised concerns about the quality of the investment decisions of plan participants. In individual accounts, households may be subject to investment mistakes such as insufficient diversification, excessive or infrequent trading, or holding too much or too little risk. ${ }^{4}$ In this context, in addition to default enrollment ${ }^{5}$ and contribution rate schedules, ${ }^{6}$ plans with default portfolio allocation rules have been put forward; see, e.g., Bodie and Treussard (2007), Viceira (2007), and Porterba et al. (2010). In a recent paper, Sialm et al. (2015) find that defined contribution plan participants indeed exhibit inertia and tend to invest in default options with a predefined portfolio share. ${ }^{7}$ We employ our calibrated life-cycle model to assess the quantitative impact of individual accounts with default portfolio allocation rules on consumption and wealth and verify the resulting utility costs. ${ }^{8}$ Clearly, default investment rules generate welfare losses, as they impose a constraint on the optimal behavior of households. The question at hand is how harmful such a constraint is. Our quantitative results suggest that welfare losses are modest. Replacing the optimal investment rule with a default rule in voluntary add-on accounts generates welfare losses of 0.17 and $0.26 \%$ of certainty-equivalent consumption relative to the scenario of a voluntary add-on account with endogenous portfolio choice.

Our paper contributes to the literature by analyzing pension reforms and optimal individual behavior in a realistically calibrated life-cycle model of portfolio choice with exogenous stochastic labor income. We build on Amromin (2003), Dammon et al. (2004), Love (2007), and Gomes et al. (2009), who study tax-efficient asset location and allocation decisions with taxable and tax-deferred accounts. In these papers, the effects of different types of individual accounts are not taken into account, which is the main purpose of our paper. Our paper is also related to Campbell et al. (2001), who analyze the effects of alternative retirement systems on consumption, wealth accumulation, and portfolio choice in a partial equilibrium 
model. However, they do not explicitly model tax-deferred defined contribution accounts. Pries (2007) introduces different personal retirement accounts into a life-cycle model but focuses mainly on labor supply distortions over the lifetime. These papers all abstract from the risk of losing retirement savings because of a financial market downturn as well as from default contribution or asset allocation rules.

A large part of the social security reform literature has focused on the potential general equilibrium impact of various reform proposals and the costs and benefits associated with the transition toward a funded system. Examples of this literature include Auerbach and Kotlikoff (1987), Feldstein and Samwick (1998), Kotlikoff (1998), De Nardi et al. (1999), and De Menil et al. (2006). Given their emphasis on general equilibrium phenomena, these papers often make simplifying assumptions about the actual decision problems that individuals face, in particular with respect to stockholding decisions.

The paper is structured as follows. Section 2 discusses individual retirement accounts in different countries. In Section 3 we present a life-cycle model of optimal portfolio choice with different types of tax-deferred individual accounts. Section 4 describes the calibration of the model and presents the quantitative findings. Finally, Section 5 concludes.

\section{INDIVIDUAL ACCOUNTS AROUND THE WORLD}

There is a common trend in public pension systems around the world: the number of defined benefit plans is declining while defined contribution plans have become increasingly important. In the United States since 2012, defined contribution plans have surpassed defined benefit plans in terms of coverage of full-time employees at medium and large private establishments. ${ }^{9}$ Individual accounts vary in structure in different retirement systems. Kritzer (2005) and Turner (2006) note that the choice depends on the country's cultural, economic, and demographic background. Voluntary defined contribution plans have grown in importance in many high-income countries and can be found in, e.g., Canada, the United Kingdom, and the United States, as well as in Germany, Switzerland, Spain, Italy, and the Scandinavian countries. Mandatory accounts were primarily introduced by countries that had to fundamentally reform their pension structures and are now found in some Latin American countries, but also in the reformed pension systems of Sweden, Denmark, and Australia. Turner (2006) categorizes individual accounts according to their relationship to social security: they can be add-on accounts or carve-out accounts from social security. An add-on account supplements the social security benefit and leaves social security contributions unaffected. A carve-out account replaces part or all of the social security benefit with benefits coming from the carve-out account. Table 1 is taken from Turner (2006) and gives an overview of the types of individual accounts in public pension systems in different countries.

In the United States there is an ongoing policy discussion on the role of individual accounts in the pension system; see Kritzer (2005), Turner (2006), and 
TABLE 1. Individual retirement accounts around the world

\begin{tabular}{|c|c|c|c|}
\hline Type of plan & Country & Name of plan & $\begin{array}{c}\text { Contribution } \\
\text { rate in } \%\end{array}$ \\
\hline $\begin{array}{l}\text { Mandatory add-on, } \\
\text { funded }\end{array}$ & $\begin{array}{l}\text { Sweden } \\
\text { Denmark } \\
\text { Switzerland } \\
\text { Australia }\end{array}$ & $\begin{array}{l}\text { Premium Pension } \\
\text { ATP } \\
\text { BVG/LPP (employer-provided) } \\
\text { Superannuation Guarantee } \\
\quad \text { charge (employer-provided) }\end{array}$ & $\begin{array}{c}2.5 \\
1.5 \\
7.0-8.0 \\
9.0\end{array}$ \\
\hline $\begin{array}{l}\text { Mandatory add-on, } \\
\text { unfunded }\end{array}$ & $\begin{array}{l}\text { Sweden } \\
\text { Italy } \\
\text { France }\end{array}$ & $\begin{array}{l}\text { Notional Account } \\
\text { Notional Account } \\
\text { ARRCO/AGIRC }\end{array}$ & $\begin{array}{l}16.5 \\
33.0 \\
14.0\end{array}$ \\
\hline $\begin{array}{l}\text { Mandatory carve-out, } \\
\text { funded }\end{array}$ & Chile & $\begin{array}{l}\text { Administradoras de Fondos } \\
\text { de Pensiones }\end{array}$ & 10.0 \\
\hline $\begin{array}{l}\text { Voluntary add-on, } \\
\text { funded }\end{array}$ & $\begin{array}{l}\text { United States } \\
\text { Canada } \\
\text { United Kingdom } \\
\text { Germany }\end{array}$ & $\begin{array}{l}\text { Individual Retirement } \\
\text { Account, 401(k) } \\
\text { Registered Pension Plan } \\
\text { Personal Pensions } \\
\text { Riester Pension }\end{array}$ & $\begin{array}{l}\$ 4,000 \\
18 \max \\
18.0 \max \\
17.5 \max \\
4.0\end{array}$ \\
\hline $\begin{array}{l}\text { Voluntary carve-out, } \\
\text { funded }\end{array}$ & $\begin{array}{l}\text { United Kingdom } \\
\text { Colombia }\end{array}$ & Approved Personal Pension & 4.6 \\
\hline
\end{tabular}

Source: Turner (2006, p. 12).

Geanakoplos and Zeldes (2009). Turner (2006) argues that the reformed social security systems of Sweden, the United Kingdom, and Chile are the most likely to influence the design of a pension reform in the United States. In 1999 Sweden reformed its defined benefit social security system by introducing mandatory supplemental individual accounts. Out of the total contribution rate to the new pension system of $18.5 \%, 2.5 \%$ is diverted to individual accounts, the "Premium Pension." Swedish participants have a choice of more than 460 different funds to choose from, with a default fund run by the government [Sunden (2006)]. Already in 1980, Chile reformed its pay-as-you-go defined benefit system by replacing it with privately managed individual accounts (full carve-out). Participants contribute $10 \%$ of their pretax salary and may also make voluntary contributions to a private pension fund of their choice. Contributions are tax-deductible, so that the government subsidizes pensions. There are different funds that participants can choose from, with a default fund that invests according to the participant's age. Since 1986, the United Kingdom's pension system has involved carve-out accounts that allow participants to voluntarily replace a part of social security with an individual account. Employees can contract out of the public defined benefit plan into an Approved Personal Pension based on individual accounts. Participants of carve-out individual accounts receive a rebate on their social security contributions, which is paid directly into the carve-out account. 
In the following, we develop a life-cycle model with exogenous stochastic labor income calibrated to the United States considering three different types of individual accounts. ${ }^{10}$ First, we consider the status quo in the United States and assume that households can save voluntarily in the tax-deferred account. Second, we consider mandatory add-on accounts as they are implemented in Sweden. Third, as in the United Kingdom, we assume that households carve out into mandatory individual accounts that partially replace the public social security system.

\section{THE LIFE-CYCLE MODEL}

We build on Gomes et al. (2009) and analyze the quantitative properties of a lifecycle portfolio choice model with exogenous stochastic labor income that features a taxable (TA) as well as an illiquid, tax-deferred (TDA) individual account. ${ }^{11}$

Households live for a maximum of $T$ periods and face an exogenous conditional survival probability at each age $t$. Households' preferences are given by

$$
E_{0} \sum_{t=0}^{T} \beta^{t}\left(\Pi_{j=0}^{t} p_{j}\right) \frac{C_{t}^{1-\rho}}{1-\rho},
$$

where $C_{t}$ is consumption and $\rho$ denotes the parameter of relative risk aversion. $0<\beta<1$ is the discount factor. $p_{j}$ denotes the probability of being alive at age $j$, conditional on $j-1$.

During working life labor income is given by

$$
\begin{aligned}
& Y_{t}=P_{t} U_{t}, \\
& P_{t}=\exp \left(f\left(t, Z_{t}\right)\right) P_{t-1} N_{t},
\end{aligned}
$$

where $f\left(t, Z_{t}\right)$ is a deterministic function of age $t$ and household characteristics $Z_{t}$. $P_{t}$ denotes the permanent component of labor income. The logs of the transitory and permanent shocks, $\ln U_{t}$ and $\ln N_{t}$, are independent and identically normally distributed with means $-0.5 \sigma_{U}^{2}$ and $-0.5 \sigma_{N}^{2}$ and variances $\sigma_{U}^{2}$ and $\sigma_{N}^{2}$, respectively. Retirement takes place exogenously at age $K$. Retirement income is characterized by a constant fraction of the last income $Y_{t}=\lambda P_{K}$, where $\lambda$ represents the replacement rate. In addition, during retirement, households withdraw wealth from their tax-deferred accounts.

The investment opportunity set consists of two assets: households can invest in a riskless asset (bond) and in a risky asset (stock) in both the TA and the illiquid TDA. There is a risk premium on holding risky assets:

$$
r_{t}^{s}-r^{b}=\mu^{s}+\epsilon_{t}^{s}
$$

$r_{t}^{s}$ and $r^{b}$ are the returns on the risky and the safe asset, respectively. $\mu^{s}$ is the mean risk premium and $\epsilon_{t}^{s}$ is independent and identically normally distributed with mean 0 and variance $\sigma_{\epsilon}^{2}$. Households pay taxes on returns in the taxable account, 
and $\tilde{r}^{s}$ denotes the after-tax return on the risky asset, whereas $\tilde{r}^{b}$ is the after-tax return on the safe asset.

Households save in the illiquid TDA because investment in the TDA is exempt from labor income taxes and retirement assets are accumulated at pretax rates of return. In addition, stock market participation is costless in the TDA, whereas in the TA, households have to pay fixed stock market entry costs that are, e.g., associated with the transaction cost from opening a brokerage account. As argued in Section 2, we consider different types of TDAs and categorize them by their relationship to social security: they can take the form of an add-on or a carve-out account. Carveout accounts reduce contributions to and benefits from social security, whereas add-on accounts do not affect the income received from the public pension system, but require additional contributions. Moreover, we distinguish individual accounts by their degree of compulsion, i.e., whether participation in individual retirement accounts is voluntary or mandatory.

\subsection{Add-On Tax-Deferred Accounts}

As a benchmark scenario, we consider voluntary add-on accounts as analyzed by Gomes et al. (2009). We assume that households can contribute a fraction of their income to the unfunded social security system and, in addition, save for retirement in the TDA. The household may invest in both accounts in a riskless as well as in a risky asset. Let $\alpha_{t}^{r}$ and $\alpha_{t}^{\tau}$ denote the shares invested in risky assets in the retirement account and taxable account, respectively. During working life, wealth in the taxable account is defined as net income plus savings, including the interest return, and evolves according to

$$
\begin{aligned}
& W_{t+1}^{\tau}=\left[\alpha_{t}^{\tau}\left(1+\tilde{r}_{t+1}^{s}\right)+\left(1-\alpha_{t}^{\tau}\right)\left(1+\tilde{r}^{b}\right)\right]\left(W_{t}^{\tau}-C_{t}-k_{t} Y_{t}\left(1-\tau_{d}\right)-I_{t} F_{t} P_{t}\right) \\
& \quad+\left(1-\tau_{d}-\tau_{s}\right) Y_{t+1}
\end{aligned}
$$

with the borrowing constraint $W_{t+1}^{\tau} \geq 0$ and the short-sell constraint $\alpha_{t}^{\tau} \in[0,1]$. $\tau_{d}$ and $\tau_{s}$ represent the labor income and social security tax, respectively. $\tilde{r}_{t+1}^{s}$ and $\tilde{r}^{b}$ are the after-tax returns on the risky and the safe asset, respectively. $k_{t} \in[0,0.2]$ denotes the endogenous contribution rate to the individual retirement account that is exempt from the labor income tax. $F_{t}$ denotes the fixed entry cost as a share of the permanent component of labor income. $I_{t}$ is an indicator function that equals 1 if the fixed entry cost is paid for the first time and zero otherwise. Households that have not yet paid the fixed cost can only invest in the riskless asset in their TA. In this case, $\alpha_{t}^{\tau}=0$.

In the illiquid TDA, savings accumulate tax-free. During working life, wealth in the retirement account is defined as TDA savings, including the interest return:

$$
W_{t+1}^{r}=\left[\alpha_{t}^{r}\left(1+r_{t+1}^{s}\right)+\left(1-\alpha_{t}^{r}\right)\left(1+r^{b}\right)\right]\left(W_{t}^{r}+k_{t} Y_{t}\right)
$$

with the borrowing constraint $W_{t+1}^{r} \geq 0$ and the short-sell constraint $\alpha_{t}^{r} \in[0,1]$. 
$r_{t+1}^{s}$ and $r^{b}$ are untaxed returns as opposed to the after-tax returns $\tilde{r}_{t+1}^{s}$ and $\tilde{r}^{b}$ imposed in the TA. ${ }^{12}$

In retirement, both constraints change to take account of the fact that households receive income from the withdrawals $Q_{t}$ of the TDA that are taxed with the labor income tax. During retirement, wealth accumulation in the TA is given by

$$
\begin{aligned}
& W_{t+1}^{\tau}=\left[\alpha_{t}^{\tau}\left(1+\tilde{r}_{t+1}^{s}\right)+\left(1-\alpha_{t}^{\tau}\right)\left(1+\tilde{r}^{b}\right)\right]\left(W_{t}^{\tau}-C_{t}+\left(1-\tau_{d}\right) Q_{t}-I_{t} F_{t} P_{t}\right) \\
& \quad+\left(1-\tau_{d}\right) Y_{t+1} .
\end{aligned}
$$

In retirement, wealth in the TDA evolves according to

$$
W_{t+1}^{r}=\left[\alpha_{t}^{r}\left(1+r_{t+1}^{s}\right)+\left(1-\alpha_{t}^{r}\right)\left(1+r^{b}\right)\right]\left(W_{t}^{r}-Q_{t}\right),
$$

with

$$
Q_{t} \geq \frac{1}{A_{t}} W_{t}^{r}
$$

denoting the minimum withdrawal rate from the TDA during retirement, which is equal to the inverse of households' life expectancy, $A_{t} \cdot{ }^{13}$

We contrast voluntary add-on accounts with mandatory add-on accounts that require households to make minimum contributions to the TDA on top of their contributions to the public pension system. In this variation of the model, households face the additional constraint $k_{t} \geq k^{\mathrm{min}}$ during working life.

\subsection{Carve-Out Tax-Deferred Accounts}

In contrast to add-on accounts, carve-out accounts replace part of the public pension system with individual accounts: households get a rebate on their social security contributions but are required to invest that amount in the TDA. The carve-out works like a loan from social security: the worker borrows from future social security benefits to invest in an individual tax-deferred retirement account. Workers repay the loan through receipt of reduced social security benefits [Turner (2006)]. To take account of the reduction of future benefits, we calculate the accumulation of carved-out contributions, $k^{c}$, in a "hypothetical account" (HA) assuming an interest rate on the hypothetical balance equal to the risk-free rate. ${ }^{14}$ These contributions are calculated from the permanent income of the household at time $t$. Upon retirement, the HA balance resulting from the crediting of contributions and interest is converted into a hypothetical annuity, based on life expectancy at that time. Social security benefits are reduced by this hypothetical annuity. With carve-out accounts, employees benefit from the higher returns that they receive over the return to their contributions that social security would give them.

During working life, the hypothetical account evolves according to

$$
W_{t+1}^{h}=\left(1+r^{b}\right) W_{t}^{h}+k^{c} P_{t}
$$


$k^{c}>0$ denotes the constant and exogenous carved-out contribution rate from social security. Accordingly, retirement income is reduced by $W_{t}^{h} / A_{t}$, where $A_{t}$ denotes the household's life expectancy at age $t$.

We consider compulsory carve-out contributions to the individual retirement accounts. During working life, the taxable account is given by

$$
\begin{aligned}
& W_{t+1}^{\tau}=\left[\alpha_{t}^{\tau}\left(1+\tilde{r}_{t+1}^{s}\right)+\left(1-\alpha_{t}^{\tau}\right)\left(1+\tilde{r}^{b}\right)\right]\left(W_{t}^{\tau}-C_{t}-k_{t} Y_{t}\left(1-\tau_{d}\right)-I_{t} F_{t} P_{t}\right) \\
& \quad+\left(1-\tau_{d}-\tau_{s}^{*}\right) Y_{t+1}
\end{aligned}
$$

with $k_{t} \geq k^{c}$, meaning that households have the opportunity to voluntarily save on top of the carved-out contributions. Because households divert part of their social security contributions $k^{c}$ to the individual retirement account, the social security contributions are reduced to $\tau_{s}^{*}=\tau_{s}-k^{c}$.

During retirement, wealth accumulation in the taxable account is given by

$$
\begin{aligned}
& W_{t+1}^{\tau}=\left[\alpha_{t}^{\tau}\left(1+\tilde{r}_{t+1}^{s}\right)+\left(1-\alpha_{t}^{\tau}\right)\left(1+\tilde{r}^{b}\right)\right]\left(W_{t}^{\tau}-C_{t}+\left(1-\tau_{d}\right) Q_{t}-I_{t} F_{t} P_{t}\right) \\
& \quad+\left(1-\tau_{d}\right)\left(Y_{t+1}-\frac{W_{t+1}^{h}}{A_{t+1}}\right)
\end{aligned}
$$

During working life and retirement, wealth accumulation in the TDA is described by equations (2) and (4), respectively.

\section{QUANTITATIVE RESULTS}

\subsection{Calibration}

To assess the quantitative properties of our life-cycle model, we calibrate the model to the U.S. economy. Table 2 summarizes the parameter values for the benchmark model. We employ the estimated gross income profiles by Fehr et al. (2005), which are based on pretax nonfinancial income.

Working life starts at age 20, retirement takes place exogenously at age 65, and the replacement rate is set to $60 \%$, which is in line with the empirical evidence for the United States [Gomes et al. (2009)]. Figure 1 displays the estimated income profiles for three different income groups. The solid line is the middle income group, which is used in the benchmark calibration. We set the variances of the permanent and temporary shocks to labor income to $10 \%$, which is in line with Carroll (1997).

We follow the household finance literature and set the parameter of relative risk aversion $\rho=4$ and the discount rate $\beta=0.95$. We assume a labor income tax equal to $25 \%$, which corresponds to the empirical average income tax of the middle income group. In the taxable account the return on bonds is taxed at a rate equal to the labor income tax. In line with the U.S. tax system, the return on bonds is taxed more highly than the return on stocks, which we calibrate to $22.5 \%$. Social 
TABLE 2. Calibration

\begin{tabular}{|c|c|c|c|}
\hline \multirow[t]{2}{*}{ Preferences } & $\rho$ & Risk aversion & 4 \\
\hline & $\beta$ & Discount rate & 0.95 \\
\hline \multirow{3}{*}{$\begin{array}{l}\text { Labor income } \\
\text { process }\end{array}$} & $\sigma_{U}$ & Transitory shock & 0.10 \\
\hline & $\sigma_{N}$ & Persistent shock & 0.10 \\
\hline & $\lambda$ & Replacement rate & 0.60 \\
\hline \multirow[t]{6}{*}{ Asset returns } & $r^{b}$ & Real bond return & 0.02 \\
\hline & $\mu^{s}$ & Equity premium & 0.04 \\
\hline & $\sigma_{\epsilon^{s}}$ & Standard deviation & 0.20 \\
\hline & $\operatorname{Corr}\left(\epsilon_{t}, \ln N_{t}\right)$ & $\begin{array}{l}\text { Corr(stock returns, } \\
\text { permanent labor inc shocks) }\end{array}$ & 0.15 \\
\hline & $\operatorname{Corr}\left(\epsilon_{t}, \ln U_{t}\right)$ & $\begin{array}{l}\text { Corr(stock returns, } \\
\text { transitory labor inc shocks) }\end{array}$ & 0 \\
\hline & $F$ & $\begin{array}{l}\text { Fixed cost of stock } \\
\text { market participation }\end{array}$ & 0.05 \\
\hline $\begin{array}{l}\text { Mandatory } \\
\text { add-on }\end{array}$ & $k^{\min }$ & $\begin{array}{l}\text { Minimum fixed } \\
\text { contribution rate }\end{array}$ & 0.03 \\
\hline $\begin{array}{l}\text { Mandatory } \\
\text { carve-out }\end{array}$ & $k^{c}$ & $\begin{array}{l}\text { Mandatory } \\
\text { carve-out rate }\end{array}$ & 0.03 \\
\hline \multirow[t]{2}{*}{$\begin{array}{l}\text { Stock market } \\
\text { disaster }\end{array}$} & $p$ & $\begin{array}{l}\text { Annual disaster } \\
\text { probability }\end{array}$ & 0.0403 \\
\hline & $\phi$ & $\begin{array}{l}\text { Stock market } \\
\text { drop }\end{array}$ & 0.278 \\
\hline
\end{tabular}

TABLE 3. Tax treatment of different income groups

\begin{tabular}{cclc}
\hline High income group & $\tau_{d}$ & Labor income tax & $35 \%$ \\
& $\tau_{b}$ & Tax on bond returns & $25 \%$ \\
& $\tau_{g}$ & Tax on stock returns & $22.5 \%$ \\
& $\tau_{s}$ & Social security tax & $6.5 \%$ \\
Middle income group & $\tau_{d}$ & Labor income tax & $25 \%$ \\
(benchmark) & $\tau_{b}$ & Tax on bond returns & $25 \%$ \\
& $\tau_{g}$ & Tax on stock returns & $22.5 \%$ \\
Low income group & $\tau_{s}$ & Social security tax & $6.5 \%$ \\
& $\tau_{d}$ & Labor income tax & $10 \%$ \\
& $\tau_{b}$ & Tax on bond returns & $25 \%$ \\
& $\tau_{g}$ & Tax on stock returns & $22.5 \%$ \\
& $\tau_{s}$ & Social security tax & $6.5 \%$ \\
\hline
\end{tabular}

security contributions for the defined-benefit system of the United States are at $6.5 \%$, to which we set the social security payroll tax in the model. ${ }^{15}$

The real bond return is set to $2 \%$ and the mean equity premium equals $4 \%$ with a standard deviation of $20 \%$. The correlation between stock returns and permanent labor income shocks is 0.15 . There is no correlation between stock 


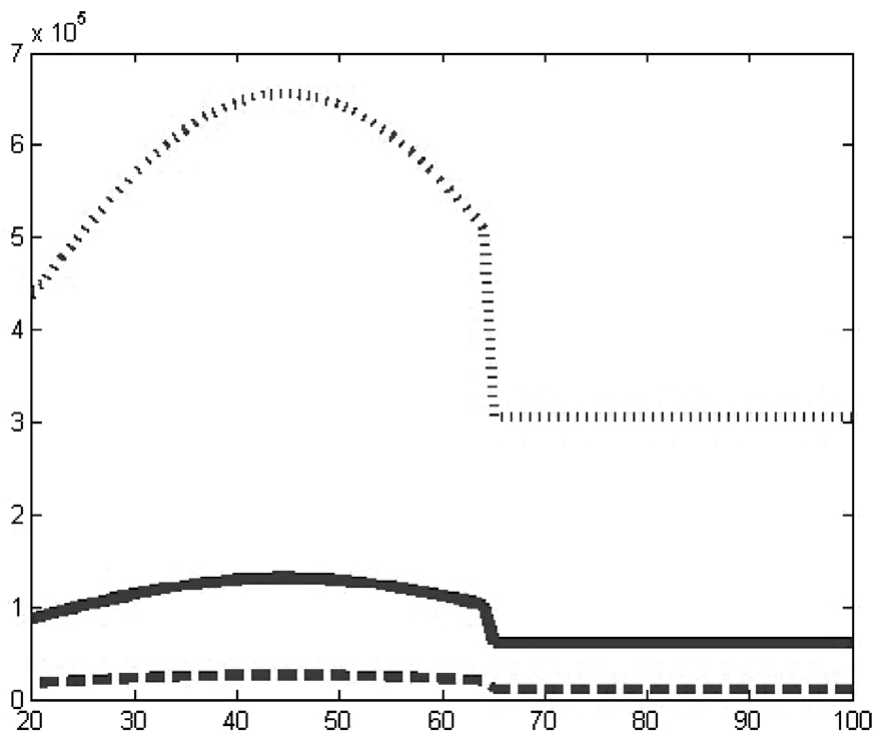

FigURE 1. Gross labor income profiles. The upper dashed line refers to gross, noncapital labor income for the high income group (college graduates), whereas the lower dashed line is the income profile of the low income group (less than high school). The solid line represents the middle income group and is the basis for the benchmark calibration. Profiles and parameters are taken from Fehr et al. (2005).

returns and transitory labor income shocks. These parameter values are standard in the literature; see, e.g., Cocco et al. (2005).

The size of the fixed stock market entry cost has been debated. Although some authors find that it is negligible, others argue that it is necessary to match stockholding over the life cycle; see, e.g., Vissing-Jorgensen (2002) and Alan (2006). We follow Gomes et al. (2009) and set the one-time fixed cost at 5\% of permanent income.

\subsection{Voluntary Add-On Accounts}

As a benchmark, we assume that households can voluntarily invest in tax-deferred individual accounts, in addition to the social security contributions. We simulate the life-cycle patterns of consumption, savings in the liquid account, contributions to the individual account, the risky shares, and the resulting wealth-to-earnings ratios for 10,000 households. We calculate the mean contribution rates to the individual account, the mean risky shares, the median wealth-to-earnings ratios in the taxable and the tax-deferred account across households, the mean consumption normalized by permanent income, and the mean share of savings devoted to the taxable account. Figure 2 shows the pattern over the life cycle (solid line), and Table 4 provides a comparison with the data across age groups. 


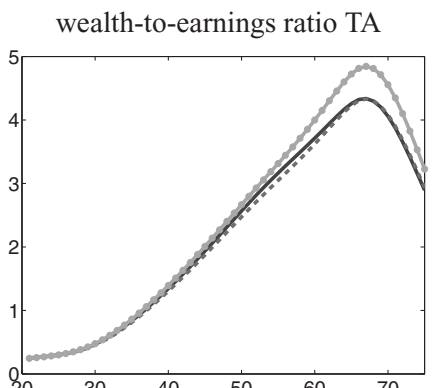

fraction invested in stocks TA

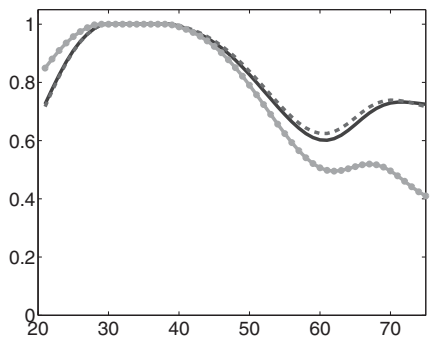

wealth-to-earnings ratio TDA

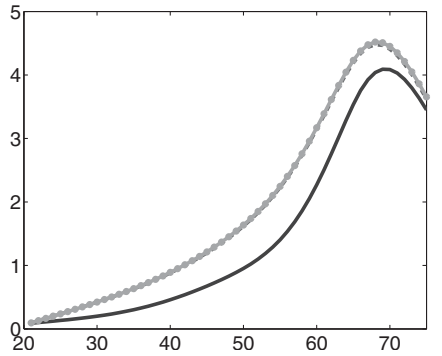

fraction invested in stocks TDA

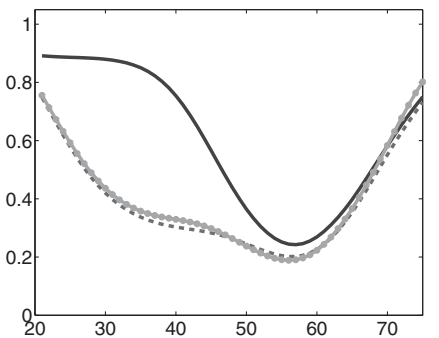

consumption
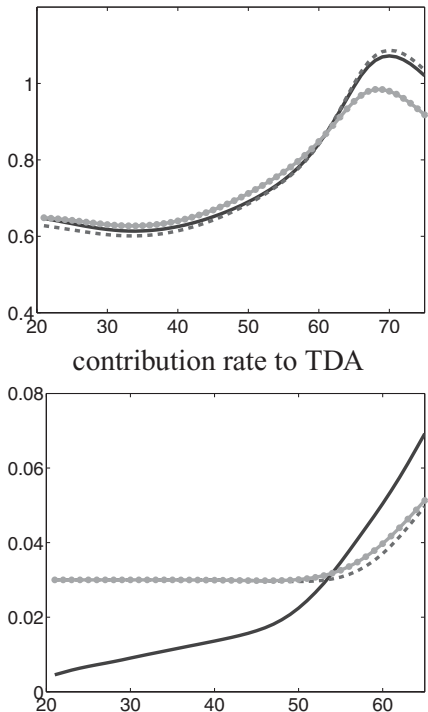

share of TA savings

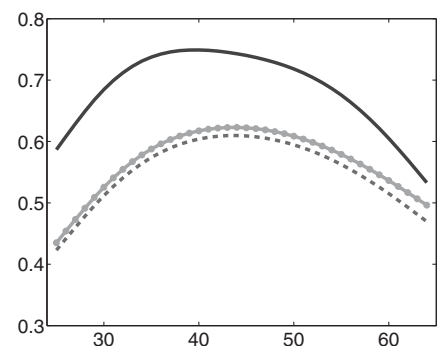

stock market participation rate

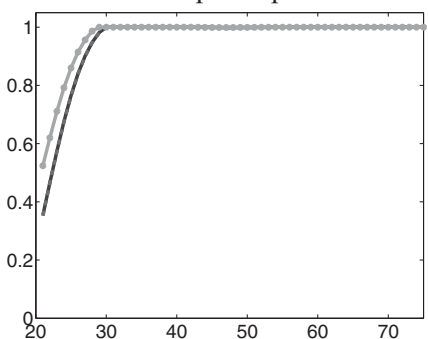

FIGURE 2. Life-cycle profiles. We simulate the life-cycle patterns for 10,000 households of the middle income group. The solid line refers to life-cycle patterns associated with voluntary add-on accounts, whereas the dashed and dashed-dotted lines correspond to life-cycle patterns associated with mandatory add-on and mandatory carve-out accounts, respectively. The panels display the median wealth-to-earnings ratio in the TA, the median wealth-to-earnings ratio in the TDA, mean consumption normalized by permanent income, the mean ratio of TA savings to total savings, the mean conditional risky share in the TA $\alpha_{t}^{t}$, the mean conditional risky share in the TDA $\alpha_{t}^{r}$, the mean contribution rate to the TDA $k_{t}$, and the stock market participation rate. 
TABLE 4. Voluntary individual accounts

\begin{tabular}{|c|c|c|c|c|}
\hline \multirow[b]{2}{*}{$\begin{array}{l}\text { Age } \\
\text { (years) }\end{array}$} & \multicolumn{2}{|c|}{ Taxable account } & \multicolumn{2}{|c|}{ Tax-deferred account } \\
\hline & $\begin{array}{l}\text { Wealth-to-earnings ratio } \\
\text { 25th/50th/75th percentile }\end{array}$ & $\begin{array}{c}\text { Mean fraction } \\
\text { invested in stocks }\end{array}$ & $\begin{array}{l}\text { Wealth-to-earnings ratio } \\
\text { 25th/50th/75th percentile }\end{array}$ & $\begin{array}{c}\text { Mean fraction } \\
\text { invested in stocks }\end{array}$ \\
\hline & \multicolumn{4}{|c|}{ Model: Benchmark } \\
\hline$<35$ & $0.30 / 0.33 / 0.49$ & 0.98 & $0.10 / 0.15 / 0.22$ & 0.82 \\
\hline $35-44$ & $0.89 / 1.25 / 1.73$ & 0.98 & $0.32 / 0.43 / 0.59$ & 0.78 \\
\hline $45-54$ & $1.78 / 2.46 / 3.34$ & 0.85 & $0.75 / 0.96 / 1.21$ & 0.39 \\
\hline $55-64$ & $2.67 / 3.52 / 4.46$ & 0.60 & $1.56 / 2.01 / 2.60$ & 0.28 \\
\hline \multirow[t]{2}{*}{$65-74$} & $2.97 / 4.13 / 5.27$ & 0.74 & $3.35 / 4.13 / 4.85$ & 0.56 \\
\hline & \multicolumn{4}{|c|}{2001 SCF data } \\
\hline$<35$ & $0.04 / 0.13 / 0.39$ & 0.61 & $0.08 / 0.20 / 0.55$ & 0.72 \\
\hline $35-44$ & $0.06 / 0.21 / 0.85$ & 0.60 & $0.17 / 0.57 / 1.38$ & 0.70 \\
\hline $45-54$ & $0.08 / 0.30 / 1.26$ & 0.58 & $0.34 / 0.94 / 2.23$ & 0.67 \\
\hline $55-65$ & $0.14 / 0.67 / 2.83$ & 0.59 & $0.37 / 1.19 / 3.52$ & 0.60 \\
\hline $65-74$ & $0.34 / 1.94 / 6.09$ & 0.56 & $0.84 / 2.19 / 6.16$ & 0.48 \\
\hline \multicolumn{5}{|c|}{ Model: Disaster expectations } \\
\hline$<35$ & $0.29 / 0.32 / 0.45$ & 0.93 & $0.10 / 0.17 / 0.25$ & 0.77 \\
\hline $35-44$ & $0.95 / 1.31 / 1.75$ & 0.56 & $0.33 / 0.42 / 0.56$ & 0.73 \\
\hline $45-54$ & $2.00 / 2.51 / 3.11$ & 0.23 & $0.62 / 0.83 / 1.12$ & 0.68 \\
\hline $55-65$ & $2.81 / 3.44 / 4.21$ & 0.14 & $1.40 / 1.90 / 2.53$ & 0.45 \\
\hline $65-74$ & $3.20 / 4.04 / 5.00$ & 0.10 & $3.04 / 3.99 / 4.86$ & 0.71 \\
\hline \multicolumn{5}{|c|}{2013 SCF data } \\
\hline$<35$ & $0.02 / 0.09 / 0.28$ & 0.49 & $0.07 / 0.20 / 0.46$ & 0.51 \\
\hline $35-44$ & $0.02 / 0.09 / 0.36$ & 0.51 & $0.16 / 0.53 / 1.14$ & 0.52 \\
\hline $45-54$ & $0.03 / 0.14 / 0.60$ & 0.55 & $0.32 / 1.03 / 1.99$ & 0.51 \\
\hline $55-65$ & $0.04 / 0.20 / 0.91$ & 0.55 & $0.47 / 1.39 / 3.27$ & 0.49 \\
\hline $65-74$ & $0.06 / 0.44 / 3.38$ & 0.60 & $0.90 / 2.43 / 5.54$ & 0.44 \\
\hline
\end{tabular}

Notes: We consider the benchmark calibration with and without disaster expectations and simulate the life-cycle patterns for 10,000 households of the middle income group. We report the statistical properties of the wealth-toearnings ratios in the taxable and tax-deferred accounts, as well as the fraction of assets invested in stocks conditional on stock market participation. We use the 2001 and 2013 SCF data with sample weights to compute the statistics. Included components of wealth and earnings are described in Appendix C.

If households save voluntarily in tax-deferred individual accounts, wealth accumulation in the TDA and TA features a hump shape over the life cycle. Young households have a high expected future income, against which they cannot borrow, and they prefer to consume most of their income and save modestly for precautionary reasons. As labor income increases and the income profile becomes less steep, from about 30 to 35 years of age, the contribution rate $k_{t}$ to the individual account starts to increase, and wealth accumulation in the retirement account rises because of the tax deferral of returns. At 15 years before retirement, agents start to increase their TDA contribution rates substantially, and save on average $6 \%$ of their annual gross income in their individual accounts when they are at age 60. This is in line with the findings of Gomes et al. (2009). The hump-shaped pattern 
of the share of savings that is devoted to the taxable account reflects the pattern of $k_{t}$ and the wealth-to-earnings ratios.

Because young households are liquidity-constrained, their marginal utility of consumption is high. As a result, they do not participate directly in the stock market until they have accumulated sufficient wealth. This happens quickly in the first few years, after which they pay the fixed entry cost. The direct participation rate in the stock market reaches $100 \%$ by the age of 30 . Conditional on stock market participation, young households allocate almost all of their assets to stocks in the TA. As households grow older and their permanent income decreases, they reduce their exposure to stocks and start investing in bonds. ${ }^{16}$ Because households do not need to pay a fixed entry cost to hold stocks in the TDA, they invest a large fraction in stocks early in life. As investors grow older, however, they increasingly shift their TDA portfolios toward bonds, the higher-taxed security, to optimize the tax-allocation of their assets. During retirement, future labor income and financial wealth in both accounts are falling. The potential number of years that households receive public pension income-a close substitute for risk-free asset holdings - decreases while financial wealth also decreases quickly. In the absence of a bequest motive, this induces investors in the model again to hold more stocks in both accounts as the end of life approaches. ${ }^{17}$

Table 4 displays the results of the voluntary add-on scenario and compares them with statistics from the data from the 2001 Survey of Consumer Finances. We choose 2001 because we want to capture household behavior net of the stock market crash that started toward the end of $2000 .{ }^{18}$ Later on, we will compare the model results with statistics produced from the 2013 survey to understand how financial downturns such as the Great Recession affect household behavior. We report the cross-sectional medians as well as the 25 th and 75 th percentiles of wealth-to-earnings ratios for both the TA and the TDA and the mean portfolio shares across age groups. ${ }^{19}$ Our measures of TA wealth include all liquid holdings of financial assets at the household level, whereas the TDA is the sum of all account-type defined contribution pension plans with information on asset allocation. Our earnings measure is the sum of all nonfinancial gross earnings of all household members. Appendix $\mathrm{C}$ provides further information regarding the data and the variable construction. ${ }^{20}$

The model generates wealth-to-earnings ratios that are in line with Gomes et al. (2009): wealth-to-earnings ratios increase with age both in the model and in the data. As Gomes et al. (2009) point out, the wealth dispersion in the data is much larger than the model can reproduce, and in particular, the wealth accumulation in the TA for lower percentiles is lower in the data than that for the model outcome. The model matches better the distribution of wealth in the TDA; however, the ranges of possible outcomes as given by the 25 th and 75 th percentiles are still wider in the data than in the model. Generally speaking, we confirm previous findings that the model cannot reproduce wealth inequality very well. The model reproduces the life-cycle pattern of risky asset holdings. However, in line with the literature on limited stockholding and low conditional risk shares, ${ }^{21}$ the model 
produces risky portfolio shares that are substantially higher than their empirical counterparts. Young investors have higher portfolio shares in both TA and TDA than older investors; however, empirical portfolio shares are lower than the ones the model produces with $62 \%(72 \%)$ for the youngest group in the TA (TDA) compared with $98 \%(82 \%)$ in the model.

There are several potential explanations for the discrepancy with the data. First, the model may overstate financial savings, as households in reality use also real estate and other nonfinancial assets to smooth consumption, investment vehicles that investors in the model cannot access. Second, we only use a single set of preference parameters to match the entire wealth distribution, but in reality there are many differences related to the investment behavior of different types of households. ${ }^{22}$ Third, our model neglects other sources of risk apart from income shocks and returns to risky assets that might tilt down the empirically observed risky portfolio share, for example house price shocks or health shocks. ${ }^{23}$

\subsection{Mandatory Add-On Accounts}

In this section, we assume that households are required to save in an individual account at a compulsory contribution rate in addition to the social security contributions. We choose a minimum fixed contribution rate of $3 \%$ of income over the entire working life, which is comparable to the mandatory add-on rate in Sweden and other countries. Households can voluntarily save more in a tax-deferred account. The dashed lines in Figure 2 show the patterns over the life cycle.

Comparing wealth-to-earnings ratios over the life cycle with those in the voluntary add-on case reveals that households that have to save for retirement in a mandatory account at young ages consequently save less of their resources in the liquid, taxable account, which reduces the wealth-to-earnings ratios. Compared with the benchmark model with voluntary add-on accounts, the introduction of minimum fixed contribution rates leads to higher median wealth-to-earnings ratios in the TDA at all ages, and the share of savings that is devoted to the taxable account is substantially lower. Voluntary contributions to the TDA above the mandatory contributions at later ages are 'crowded out'. Although households with a voluntary add-on account make very small contributions in younger ages and increase their retirement savings from age 35 onward, households with mandatory addon accounts have to invest $3 \%$ of their annual gross labor income for retirement from the beginning of their working lives, when they would rather consume and save less in the tax-deferred account during the prime years of retirement saving. Making add-on accounts mandatory decreases consumption during working life but increases consumption during retirement. Although portfolio choices in the liquid account are hardly affected by the mandatory contributions to the individual account, households shift their TDA portfolios toward the safer asset. Households invest a substantial share in risky assets in the TDA only at older ages. The higher wealth-income ratios in the TDA and the optimal tax allocation of assets induce households to invest their retirement savings in bonds. 
TABLE 5. Utility costs

\begin{tabular}{lcccccccc}
\hline & \multicolumn{3}{c}{ Mandatory add-on } & & \multicolumn{3}{c}{ Mandatory carve-out } \\
\cline { 2 - 4 } \cline { 7 - 9 } & $k=0.02$ & $k=0.03$ & $k=0.04$ & & $k=0.02$ & $k=0.03$ & $k=0.04$ \\
\hline High income group & 0.55 & 1.46 & 2.54 & & -2.13 & -2.55 & -2.86 \\
Middle income group & 0.59 & 1.49 & 2.58 & & -1.65 & -2.03 & -2.18 \\
Low income group & 0.57 & 1.46 & 2.51 & & -1.27 & -1.39 & -1.37 \\
\hline
\end{tabular}

Notes: This table considers the benchmark calibration and evaluates the welfare consequences of different types of individual accounts across income groups. The utility costs of mandatory add-on and carve-out accounts are given relative to the voluntary add-on account. For each scenario, we calculate the constant consumption stream that makes the household as well-off in terms of expected utility. Utility costs are calculated as percentage deviations in certainty-equivalent consumption relative to the voluntary add-on account.

To evaluate the welfare consequences of mandatory add-on accounts, we facilitate a comparison with voluntary accounts by calculating the constant consumption stream that makes the household as well off in terms of expected utility. ${ }^{24}$ Table 5 displays the welfare losses calculated in terms of percentage deviations in certainty-equivalent consumption relative to the voluntary add-on scenario assuming different mandatory contribution rates. Households living in the mandatory-add-on world with a minimum contribution rate of $3 \%$ suffer losses of approximately $1.5 \%$ of certainty-equivalent consumption, reflecting the adverse effects of compulsory savings for retirement in young years when they would prefer to consume more. As expected, welfare losses are larger if larger mandatory contribution rates are assumed.

\subsection{Mandatory Carve-Out Accounts}

Mandatory carve-out accounts have two effects. First, they increase households' net income by giving them a rebate on their social security contributions, and second, households have to invest the carved-out amount in the tax-deferred account. In retirement, their income from the unfunded public system is reduced by the annuitized amount to which their carve-out saving rate would have accumulated when invested at the risk-free rate.

The dashed-dotted lines in Figure 2 show the life-cycle patterns associated with mandatory carve-out accounts. A comparison of the carve-out and the addon scenarios reveals that the mandatory carve-out account generates higher savings in both the individual account and the liquid taxable account until agents are in retirement. This is due to the tax savings they encounter: households benefit from a positive income effect because of the reduced social security contributions. This results in higher consumption levels during working life compared with the voluntary add-on scenario. When households retire, they have accumulated more wealth in the individual account compared with the other two scenarios. Their higher private retirement wealth compensates for the loss in public pension benefits. ${ }^{25}$

The welfare analysis in Table 5 suggests that carve-out accounts have a positive impact on the welfare of households because of the benefits of converting social 
security contributions into individually managed tax-deferred accounts with optimally chosen risky portfolio shares. It turns out that households experience a welfare gain of approximately $2 \%$ of certainty-equivalent consumption relative to the voluntary add-on scenario. These gains increase (decrease) if higher (lower) minimum contribution rates are considered.

\subsection{Different Income Groups}

In many countries, the introduction of tax-deferred retirement plans is motivated by the envisaged advantages that low and middle income earners gain from such public policy. For example, low income earners are often less financially literate, ${ }^{26}$ and offering retirement savings plans may enable these households to benefit from the equity premium through low-cost participation in the stock market. ${ }^{27} \mathrm{We}$ therefore solve and simulate our model for the optimal behavior of high and low income groups that can be identified with our income profiles in Figure $1 .^{28}$ In accordance with the tax brackets of the United States and other countries, higher income earners pay higher taxes than lower income earners. Table 3 displays the average tax rates that are paid by the high, middle, and low income groups as they are observed in the United States in 2001.

Table 5 shows that the associated welfare effects arising from access to the different types of TDAs differ across income groups. Households in the highest income group have the strongest incentive to participate in the TDA, as they benefit the most from the tax deferral. In comparison with the voluntary add-on account, carve-out accounts generate substantial welfare gains of around $2.55 \%$ for the high income earners. The welfare gains from mandatory carve-out accounts are the lowest for low income earners, as they benefit less from the tax-deferral of individual accounts. In contrast to the carve-out account, a mandatory add-on account leads to welfare losses for all income groups, and the higher the mandatory contribution rate, the higher the welfare loss. It is interesting to note that the low income group suffers (slightly) less from the mandatory add-on account than the middle income group. This is due to the flat income profile of low income earners over the life cycle, in comparison with the pronounced hump shape of labor income for middle and high income earners. Low income earners prefer to have a flat contribution schedule over all of their working life, whereas middle and high income earners prefer to save less when they are young and when their income profile is steep and their marginal propensity to consume is high. They optimally increase their contributions to the individual account as they age and the income profile is less steep.

\subsection{Rare Stock Market Disasters}

In view of the recent financial turmoil, it has become particular important to understand the influence of stock market crashes on households' retirement savings, their portfolio choices, and the role of individual accounts. We now focus on the 
2013 data to capture households' portfolios in the aftermath of a stock market disaster such as the Great Recession. The lower panel of Table 4 displays wealthto-earnings ratios in the TA and the TDA and the respective portfolio shares for the 2013 SCF. $^{29}$ Wealth-to-earnings ratios in both accounts are lower than in 2001 , and the whole distribution is shifted to the left; in particular, the median and the 75 th percentile of wealth-to-earnings ratios have decreased. The risky portfolio shares in both accounts have dropped substantially in comparison to the 2001 data. Households in the youngest age groups hold only roughly $50 \%$ of their assets in stocks in both TA and TDA.

Against the empirical evidence of the drop in risky portfolio shares in times of crisis, we now explicitly incorporate the risk of a financial market downturn into our model and analyze the impact of disaster expectations on optimal retirement savings in individual accounts. We follow Alan (2012) and introduce disaster expectations by assuming that households face a small probability of experiencing a stock market disaster in each period when they update their expectations. In case a disaster strikes, a large portion of the household's stock market wealth evaporates and households face a negative return of $\phi$. We use the estimated disaster probabilities and stock market drops for the United States by Barro and Ursua (2008). The probability of a disaster for the United States is assumed to be $4.03 \%$ and the negative return in case of a disaster is on the average $27.8 \% .^{30}$

To visualize the impact of the perceived risk of a financial downturn, Figure 3 presents the life-cycle patterns generated by the model that incorporates the probability of a stock market crash. The solid lines refer to voluntary add-on accounts, whereas the dashed and dashed-dotted lines refer to mandatary add-on and mandatory carve-out accounts, respectively.

Figure 3 shows that introducing a small probability of a financial market downturn affects the optimal portfolio choices substantially. During working life, households are now subject to risky labor income and-in addition-face the risk of a stock market crash. Households save a large fraction of their TA wealth in stocks only at the beginning of their lives and reduce their stock market exposure quickly as they age. The decrease in the risky portfolio share is modest in the voluntary add-on account, as the effect of the stock market risk will only affect households after retirement, when they have certain labor income. However, the increased stock market risk reduces the contribution rate to the illiquid individual account after the initial years of the life cycle. If individual accounts are mandatory with a fixed minimum contribution rate, the risk of a stock market disaster decreases the risky portfolio share in the TDA to levels similar to the data (see Table 4). We conclude from this model exercise that disaster expectations in portfolio choice models can go some way in explaining the empirically observed low risky portfolio shares of households.

The first row of Table 6 summarizes the utility costs of the different types of individual retirement accounts in the presence of rare stock market disasters. It turns out that the welfare implications are similar to those in our benchmark scenario. 
wealth-to-earnings ratio TA

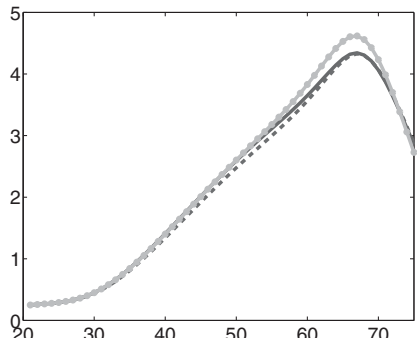

fraction invested in stocks TA

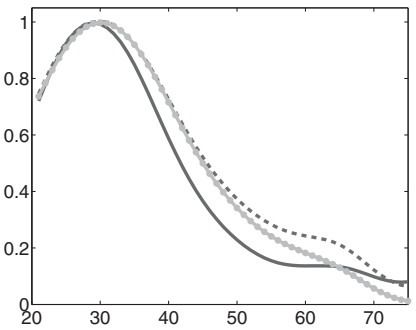

wealth-to-earnings ratio TDA

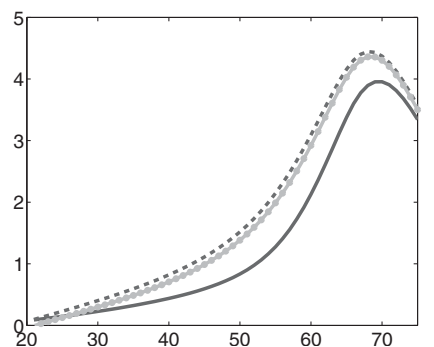

fraction invested in stocks TDA

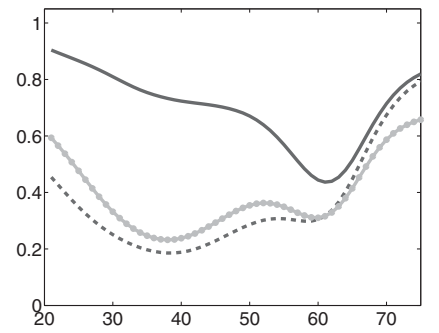

consumption

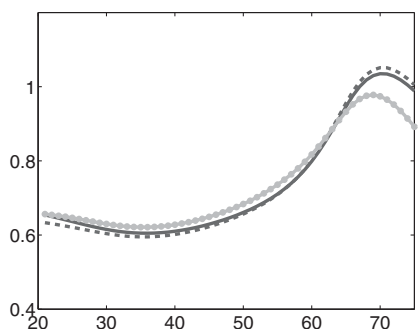

contribution rate to TDA

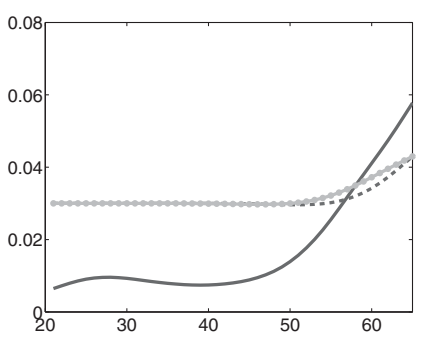

share of TA savings

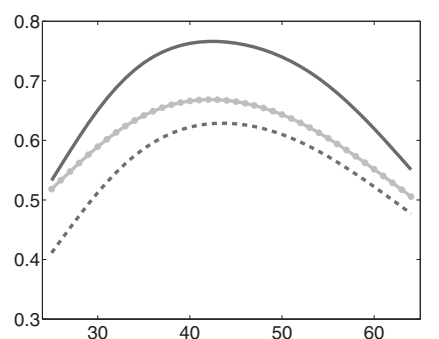

stock market participation rate

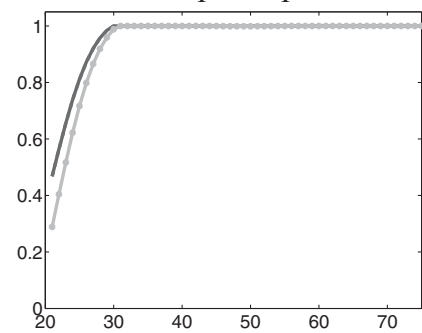

FIGURE 3. Life-cycle profiles with disaster expectations. We simulate the life-cycle patterns for 10,000 households of the middle income group considering the probabilities of rare stock market crashes. The solid line refers to life-cycle patterns associated with voluntary add-on accounts, whereas the dashed and dashed-dotted lines correspond to life-cycle patterns associated with mandatory add-on and mandatory carve-out accounts, respectively. The panels display the median wealth-to-earnings ratio in the TA, the median wealth-to-earnings ratio in the TDA, mean consumption normalized by permanent income, the mean ratio of TA savings to total savings, the mean conditional risky share in the TA $\alpha_{t}^{t}$, the mean conditional risky share in the TDA $\alpha_{t}^{r}$, the mean contribution rate to the TDA $k_{t}$, and the stock market participation rate. 
TABLE 6. Utility costs: Disaster expectations and default investment rules

\begin{tabular}{lccccccc}
\hline & \multicolumn{3}{c}{ Model: Benchmark } & & \multicolumn{3}{c}{ Model: Disaster expectations } \\
\cline { 2 - 3 } \cline { 7 - 8 } & $\begin{array}{c}\text { Voluntary } \\
\text { add-on }\end{array}$ & $\begin{array}{c}\text { Mandatory } \\
\text { add-on }\end{array}$ & $\begin{array}{c}\text { Mandatory } \\
\text { carve-out }\end{array}$ & & $\begin{array}{c}\text { Voluntary } \\
\text { add-on }\end{array}$ & $\begin{array}{c}\text { Mandatory } \\
\text { add-on }\end{array}$ & $\begin{array}{c}\text { Mandatory } \\
\text { carve-out }\end{array}$ \\
\hline Optimal $\alpha^{r}$ & - & 1.49 & -2.03 & & - & 1.29 & -2.40 \\
Age rule & 0.17 & 1.55 & -1.98 & & 0.11 & 1.31 & -2.37 \\
50-50 rule & 0.26 & 1.56 & -1.96 & & 0.14 & 1.33 & -2.35 \\
\hline
\end{tabular}

Notes: This table evaluates the welfare consequences of different types of individual accounts in the presence of default investment rules and disaster expectations. The utility costs of mandatory add-on and carve-out accounts are given relative to the voluntary add-on account with optimal $\alpha^{r}$. For each scenario, we calculate the constant consumption stream that makes the household as well-off in terms of expected utility. Utility costs are calculated as percentage deviations in certainty-equivalent consumption relative to the voluntary add-on account with optimal $\alpha^{r}$.

\subsection{Default Portfolio Rules}

The worldwide trend toward individual accounts in which investment decisions are made by the plan participants themselves has raised concerns about the quality of the investment decisions. Many authors have pointed out the lack of financial sophistication that results in low participation rates, inertia in portfolio choices, and limited diversification; see, e.g., Bernartzi and Thaler (2001), Agnew et al. (2003), Bernartzi and Thaler (2004), Campbell (2006), Turner (2006), Calvet et al. (2007), Lusardi and Mitchell (2007), and Lusardi and Mitchell (2011). Because investment mistakes may imply considerable welfare costs, default portfolio allocation rules (such as life-cycle funds) have been put forward in the context of DC pension plans; see, e.g., Bodie and Treussard (2007), Viceira (2007), and Porterba et al. (2010). Typical default portfolio allocations are risky shares that are inversely related to the participants' age or consist of simple investment targets such as 50\% of the portfolio in stocks and $50 \%$ in bonds. ${ }^{31}$

In our model, default investment rules generate welfare losses, as they impose a constraint on the optimal behavior of households. The objective of this section is to analyze how harmful such a constraint is. Gomes et al. (2008) calculate the welfare costs of employing different types of default investment rules in a model with flexible labor supply. They show that a typical life-cycle fund, in which investment in stocks is inversely related to age, generates minimal deviations in consumption and wealth accumulation when compared with the optimal choices, so that welfare losses are moderate. In the following, we pursue a similar analysis to evaluate the welfare costs of default rules in different types of individual accounts.

We study the effects of a default portfolio allocation rule on households' savings decisions assuming voluntary and mandatory add-on accounts as well as mandatory carve-out plans. We consider the benchmark calibration as well as the model that incorporates the risk of a stock market disaster. The first default rule fixes the risky share in the TDA depending on age, thereby exogenously mimicking a life-cycle fund where the risky share is falling as the participant 
gets older, $\alpha_{t}^{r}=(100-$ age $) \%$. As an alternative, we assume that $50 \%$ of the savings in the TDA are invested in stocks and the remaining 50\% are invested in bonds, which is also roughly what the data suggest. Both default rules have been put forward in the finance literature [Bodie and Treussard (2007); Viceira (2007); Gomes et al. (2008)], the first as a result of the findings of Jagannathan and Kocherlakota (1996), namely that older investors optimally hold less in stocks; the second as a commonly used rule of thumb to split up financial resources over available investment vehicles.

The welfare consequences of a default rule depend on how much a default rule distorts optimal portfolio choice. As discussed earlier, because investors optimally invest less in stocks as they age, the life-cycle patterns of the age rule differ only slightly from the case of the optimally chosen risky shares. Because the optimal risky share in the TDA over the entire life cycle is not too far from 50\%, welfare costs of the simple rule of thumb are not too high either. As a result, as Table 6 shows, default portfolio rules generate rather modest adverse welfare effects. For the benchmark model, welfare losses are approximately in the range of 0.17 and $0.26 \%$ of certainty-equivalent consumption relative to the scenario of a voluntary add-on account with endogenous portfolio choice.

In the case with a disaster scenario when households cannot adjust their portfolio shares, welfare costs turn out to be slightly lower than without disaster expectations, which is due to the lower optimal risky portfolio shares, which are closer to the default rules.

\section{DISCUSSION AND CONCLUSIONS}

In this paper, we have analyzed life-cycle saving, wealth accumulation, and portfolio allocation decisions in a model with a taxable account and a funded, taxdeferred individual account in the presence of uninsurable labor income risk and borrowing constraints. We have varied the roles that individual retirement accounts assume in the public social security system and have examined the effects on households' life-cycle decisions depending on the type of account implemented. In addition, we have analyzed the impact of a perceived risk of financial market downturn on optimal retirement savings in individual accounts.

Our results are limited by the experimental nature of our model exercises; however, we have gained some useful insights into the incentives that TDAs pose for participating households. Our results confirm the hypothesis that forcing agents to save a minimum fraction of their income crowds out retirement savings they would voluntarily undertake at later stages in life, generating welfare losses of $1.5 \%$ measured in certainty-equivalent consumption across income groups. Mandatory carve-out accounts, in contrast, have positive welfare effects because of the benefits of converting social security contributions into individually managed TDAs with optimally chosen risky portfolio shares. For the low income group, however, mandatory carve-out accounts generate the lowest welfare gains, as low income earners benefit less from tax deferral. Including default portfolio rules 
in individual accounts, which is a standard practice in reality, generates modest welfare effects.

Our quantitative analysis has shown that the perceived risk of a financial market downturn affects the optimal portfolio choices substantially and brings the model closer to the data. At the same time, the welfare implications associated with the different types of individual accounts under the disaster scenario are robust.

In our model, households that live in a world where financial crises can occur are limited in their optimizing behavior, as they can only reshuffle their risky portfolio shares to a safer investment option and adjust the level of their (financial) savings, both liquid and illiquid. In reality, households can insure themselves against crises by building up a stock of real assets. Moreover, households have more options to insure themselves against the devastating effects of a financial disaster: they can decide to work longer years and increase their retirement benefits. Goda et al. (2011) and Helppie McFall (2011) provide recent evidence that TDA participants responded to the sharp downturn of stock prices during the Great Recession by prolonging their working years. We leave the important question of savings in individual accounts and labor supply decisions in times of a stock market crash to future research.

Our paper has focused on the partial effects of individual accounts on households' savings and portfolio allocation decisions only. The introduction of different types of tax-deferred accounts, however, has general equilibrium effects on the entire economy, as tax revenues are influenced. In addition, introducing carve-out accounts decreases the value of social security contributions and has potentially severe fiscal consequences during the period of transition from an unfunded system to a system that is partially funded. Therefore, it is of particular interest for future research to analyze the general equilibrium effects of different types of individual accounts along the transition paths.

\section{NOTES}

1. See President's Commission to Strengthen Social Security (2001) and Geanakoplos and Zeldes (2009).

2. See the papers on retirement plans and the Great Recession in the May 2011 edition of the American Economic Review.

3. Alan (2012) shows that the perceived risk of a stock market disaster significantly reduces stock market participation and stockholding in a life-cycle model. Her model, however, abstracts from tax-deferred individual accounts.

4. Survey-based evidence on households' financial capabilities shows that a consistent fraction of the population lacks basic financial knowledge. Studies that focus on the quality of the investment decisions are, e.g., Bernartzi and Thaler (2001), Agnew et al. (2003), Bernartzi and Thaler (2004), Turner (2006), Calvet et al. (2007), Lusardi and Mitchell (2007), and Lusardi and Mitchell (2011).

5. See, e.g., Madrian and Shea (2001), Choi et al. (2002), Choi et al. (2004), Bernartzi and Thaler (2007), and Carroll et al. (2009), who propose automatic enrollment policies with an option to opt-out.

6. See, e.g., Bernartzi and Thaler (2004) and Pries (2007).

7. They show that fund sponsors counteract the inertia of plan participants and offset the infrequent trading by plan participants. 
8. See Bernheim et al. (2015) for an overview of welfare costs for default options in 401(k) plans.

9. See Sialm et al. (2015).

10. This is by no means a complete description of individual accounts, which can have many additional features in reality. For an extended overview of the types of different individual retirement accounts in the social security systems of different countries, see Turner (2006).

11. In our model, we make the simplifying assumption that the TDA is completely illiquid during working life and households gain access to their retirement savings only as they retire. In reality, retirement accounts are de facto illiquid, as withdrawals are subject to penalties and individuals gain access to TDAs as they reach a prespecified age, which does not have to coincide exactly with their entry to retirement. See Holden et al. (2005) for details on the rules of TDAs in the United States.

12. In our model, there is no employer matching; i.e., households only benefit from the tax deferral of their own savings. Employer matching, of course, makes saving in the TDA more beneficial, as the employer matches the contribution of households one to one up to a certain cap.

13. This matches the minimum distribution requirements of DC pension plans in the United States.

14. The trade-off between contributions to an individual carve-out account and the reduction in the future payout of social security is one of the most important aspects in the design of a carve-out account, as it directly affects the generosity of the carve-out account for participants and the related costs to the government. The debate about the "right" interest rate for the benefit offset is also reflected by the report of the President's Commission (President's Commission to Strengthen Social Security (2001)), which includes three different possible rates. An interest rate in the hypothetical account below the risk-free rate implies that the individual account is subsidized by the social security system. An interest rate equal to the bond rate means there is no subsidy, which we assume here.

15. We assume that all employees pay $6.5 \%$ of their gross wages as contributions, irrespective of their income; i.e., there is no limit on the wages on which the social security contribution is paid, such as the Social Security Wage Base.

16. The substitutability between riskless financial assets and the future labor income stream has been put forward by Jagannathan and Kocherlakota (1996) and has been adapted in the portfolio choice literature by Cocco et al. (2005). The basic idea is that even though income is subject to shocks, it is still a better substitute for the risk-free asset than the risky asset in an agent's portfolio choice problem. As investors age and their implicit holding of the riskless asset in the form of income decreases, they increase their explicit holdings of the riskless asset in the form of bonds.

17. Introducing bequests would lower the risky portfolio shares toward the end of life, as financial wealth would not be depleted so quickly; see, e.g, Cocco et al. (2005), Gomes and Michaelides (2005).

18. Gomes et al. (2009) compare their model results with the 2004 cross section of the SCF and note that the 2001 survey might be closer to what their model predicts because of the effects of the 2000/2001 financial crisis. We also calculated all statistics for the 2004 survey and found that indeed the portfolio shares are lower.

19. We report medians rather than means because the wealth distribution is heavily skewed.

20. It is important to note that the data are a cross-sectional glance at how young and old households invest, and in particular, that we cannot control for age, time, and cohort effects at the same time.

21. See, e.g., Guiso et al. (2003), Guiso et al. (2002), Cocco et al. (2005), Gomes and Michaelides (2005), Haliassos (2008).

22. For example, Gomes et al. (2009) differentiate between indirect and direct stockholders and give them different preference parameters.

23. See, e.g., Cocco et al. (2005) for a portfolio choice model with housing and risks to house returns.

24. Details are provided in the Appendix.

25. After their carved-out contributions are deducted from the public pension benefit, their replacement rate amounts to $37 \%$ instead of $60 \%$ of their last working life income.

26. Households with lower education and incomes have been shown to be more prone to investment mistakes; see Campbell (2006). 
27. Because our stylized model does not capture the financial literacy of different household types, the different income profiles serve also as a proxy for differences in financial sophistication.

28. In our calibration, low, middle, and high income groups only differ by their income levels and the diverse tax rates paid on these. Realistically calibrated income shocks should be different for different education groups; see, e.g., Carroll (1997), Cocco et al. (2005). Including different transitory and permanent shocks would leave our results qualitatively unchanged. There would be slight quantitative differences: Including higher transitory and permanent shocks for low-income households would lead to higher uncertainty and therefore a more prudent portfolio choice and lower consumption, whereas a higher permanent shock for the high income group would make the high income group only slightly worse off in comparison with our results. Abstracting from different shocks allows us to focus on the tax incentives of the different income groups only.

29. When comparing statistics from the two waves, note again that the data are cross-sectional and that we do not capture the same households as in 2001.

30. In principle, one can think of many implications that disasters might have in our model. For example, they might have effects on social security income $\lambda Y_{K}$, wage income $Y_{t}$, and the bond return $r^{b}$. Our focus is on the risky portfolio location and allocation decisions in the TA and the TDA. We therefore abstract from any other influence of macroeconomic disasters and isolate the effects that a drop in the stock return has on portfolio choice and tax-efficient behavior. Introducing such additional features of a recession would, however, be easy to implement. In our model, any further uncertainty driven by a recession would lead to additional background risk and higher bond holdings.

31. See Viceira (2007) and the references in Bodie et al. (2007).

\section{REFERENCES}

Agnew, Julie, Pierluigi Balduzzi, and Annika Sunden (2003) Portfolio choice and trading in a large 401(k) plan. American Economic Review 93(1), 193-215.

Alan, Sule (2006) Entry costs and stock market participation over the life cycle. Review of Economic Dynamics 9, 588-611.

Alan, Sule (2012) Do disaster expectations explain household portfolios? Quantitative Economics 3, $1-28$.

Amromin, Gene (2003) Household portfolio choices in taxable and tax-deferred accounts: Another puzzle. European Finance Review 7, 547-582.

Auerbach, Alan J. and Lawrence J. Kotlikoff (1987) Dynamic Fiscal Policy. Cambridge, UK: Cambridge University Press.

Barro, Robert J. and Jose F. Ursua (2008) Macroeconomic crises since 1870. Brookings Papers on Economic Activity 39(1), 255-335.

Bernartzi, Shlomo and Richard H. Thaler (2001) Naive diversification strategies in defined contribution saving plans. American Economic Review 91(1), 79-98.

Bernartzi, Shlomo and Richard H. Thaler (2004) Save more for tomorrow: Using behavioral economics to increase employee saving. Journal of Political Economy 112(1), 164-187.

Bernartzi, Shlomo and Richard H. Thaler (2007) Heuristics and biases in retirement savings behavior. Journal of Economic Perspectives 21(3), 81-104.

Bernheim, Douglas, Andrey Fradkin, and Igor Popov (2015) The welfare economics of default options in 401(k) plans. American Economic Review 105(9), 2798-2837.

Bodie, Zvi, Dennis McLeavey, and Laurence B. Siegel (2007) The Future of Life-Cycle Saving and Investing. The Research Foundation of CFA.

Bodie, Zvi and Jonathan Treussard (2007) Making investment choices as simple as possible, but not simpler. Financial Analysts Journal 63(3), 16-17.

Calvet, Laurent E., John Y. Campbell, and Paolo Sodini (2007) Down or out: Assessing the welfare costs of household investment mistakes. Journal of Political Economy 115, 707-747.

Campbell, John Y. (2006) Household finance, presidential address to the American Finance Association. Journal of Finance 61(4), 1553-1604. 
Campbell, John Y., Joao F. Cocco, Francisco J. Gomes, and Pascal J. Maenhout (2001) Investing retirement wealth: A life-cycle model. In John Y. Campbell and Martin Feldstein (eds.), Risk Aspects of Investment-Based Social Security Reform, pp. 439-482. Chicago: University of Chicago Press.

Carroll, Christopher D. (1997) Buffer-stock saving and the life-cycle/permanent income hypothesis. Quarterly Journal of Economics 110(1), 1-55.

Carroll, Gabriel D., James J. Choi, David Laibson, Brigitte C. Madrian, and Andrew Metrick (2009) Optimal defaults and active decisions. Quarterly Journal of Economics 124(4), 1639-1674.

Choi, James, David Laibson, Brigitte C. Madrian, and Andrew Metrick (2002) Defined contribution pensions: Plan rules, participant decisions, and the path of least resistance. In James Poterba (ed.), Tax Policy and the Economy, Vol. 16, pp. 67-113. Cambridge, MA: MIT Press.

Choi, James, David Laibson, Brigitte C. Madrian, and Andrew Metrick (2004) For better or for worse: Default effects and 401(k) savings behavior. In David A. Wise (ed.), Perspectives in the Economics of Aging, pp. 81-125. Chicago: University of Chicago Press.

Cocco, Joao, Francisco Gomes, and Pascal J. Maenhout (2005) Consumption and portfolio choice over the life cycle. Review of Financial Studies 18(2), 491-533.

Dammon, Robert M., Chester S. Spatt, and Harold H. Zhang (2004) Optimal asset location and allocation with taxable and tax-deferred investing. Journal of Finance 59(3), 999-1037.

De Menil, Georges, Fabrice Murtin, and Eytan Sheshinski (2006) Planning for the optimal mix of paygo tax and funded savings. Journal of Pension Economics and Finance 5(1), 1-25.

De Nardi, Mariacristina, Selahattin Imrohoroglu, and Thomas J. Sargent (1999) Projected U.S. demographics and social security. Review of Economic Dynamics 2, 575-615.

Fehr, Hans, Sabine Jokisch, and Laurence J. Kotlikoff (2005) Will China Eat Our Lunch or Take Us out to Dinner? Simulating the Transition Paths of the U.S., EU, Japan and China. NBER working paper 11668.

Feldstein, Martin and Andrew Samwick (1998) The transition path in privatizing Social Security. In Martin Feldstein (ed.), Privatizing Social Security, pp. 215-260. Chicago: University of Chicago Press.

Geanakoplos, John and Stephen P. Zeldes (2009) Reforming social security with progressive personal accounts. In Jeffrey R. Brown, Jeffrey B. Liebman, and David A. Wise (eds.), Social Security Policy in a Changing Environment, pp. 73-128. Chicago: University of Chicago Press.

Goda, Gopi Shah, John B. Shoven, and Sita Nataraj Slavov (2011) What explains changes in retirement plans during the Great Recession? American Economic Review 101(3), 29-34.

Gomes, Francisco, Laurence J. Kotlikoff, and Luis M. Viceira (2008) Optimal life-cycle investing with flexible labor supply: A welfare analysis of life-cycle funds. American Economic Review: Papers and Proceedings 98(2), 297-303.

Gomes, Francisco and Alexander Michaelides (2005) Optimal life-cycle asset allocation. Journal of Finance 60(2), 869-904.

Gomes, Francisco, Alexander Michaelides, and Valery Polkovnichenko (2009) Optimal savings with taxable and tax-deferred accounts. Review of Economic Dynamics 12, 718-735.

Guiso, Luigi, Michael Haliassos, and Tullio Jappelli (2002) Household portfolios: An international comparison. In Luigi Guiso, Michael Haliassos, and Tullio Jappelli (eds.), Household Portfolios, pp. 1-24. Cambridge, MA: MIT Press.

Guiso, Luigi, Michael Haliassos, and Tullio Jappelli (2003) Household stockholding in Europe: Where do we stand and where do we go? Economic Policy 36, 123-170.

Haliassos, Michael (2008) Household portfolios. In Steven N. Durlauf and Lawrence E. Blume (eds.), New Palgrave Dictionary of Economics, 2nd ed., London: Palgrave Macmillan.

Helppie McFall, Brooke (2011) Crash and wait? The impact of the Great Recession on the retirement plans of older Americans. American Economic Review 101(3), 40-44.

Holden, Sarah, Kathy Ireland, Vicky Leonard-Chambers, and Michael Bogdan (2005) The individual retirement account at age 30: A retrospective. Investment Company Institute Perspective 11(1), $1-24$. 
Jagannathan, Ravi and Naryana R. Kocherlakota (1996) Why should older people invest less in stocks than younger people? Federal Reserve Bank of Minneapolis Quarterly Review 20(3), 1123.

Kotlikoff, Lawrence J. (1998) Simulating the privatization of Social Security in general equilibrium. In Martin Feldstein (ed.), Privatizing Social Security, pp. 265-306. Chicago: University of Chicago Press.

Kritzer, Barbara E. (2005) Individual accounts in other countries. Social Security Bulletin 66(1), 31-37.

Love, David A. (2007) What can the life-cycle model tell us about 401(k) contributions and participation? Journal of Pension Economics and Finance 6(2), 147-185.

Lusardi, Annamaria and Olivia S. Mitchell (2007) Financial literacy and retirement preparedness: Evidence and implications for financial education programs. Business Economics 42(1), 3544.

Lusardi, Annamaria and Olivia Mitchell (2011) Financial Literacy Around the World: An Overview. NBER working paper 17107.

Madrian, Brigitte and Dennis Shea (2001) The power of suggestion: Inertia in 401(k) participation and savings behavior. Quarterly Journal of Economics 66(4), 1149-1187.

Porterba, James, Joshua Rau, Steven Venti, and David A. Wise (2010) Lifecycle asset allocation strategies and the distribution of 401(k) retirement wealth. In David A. Wise (ed.), Developments in the Economics of Aging, pp. 15-50. Chicago: University of Chicago Press.

President's Commission to Strengthen Social Security. (2001) Strengthening Social Security and Creating Personal Wealth for All Americans: Report of the President's Commission. Washington, DC: President's Commission to Strengthen Social Security.

Pries, Michael J. (2007) Social security reform and intertemporal smoothing. Journal of Economic Dynamics and Control 31, 25-54.

Sialm, Clemens, Laura Starks, and Hanjiang Zhang (2015) Defined contribution pension plans: Sticky or discerning money? Journal of Finance 70(2), 805-838.

Sunden, Annika (2006) The Swedish experience with pension reform. Oxford Review of Economic Policy 22(1), 133-148.

Turner, John (2006) Individual Accounts for Social Security Reform: International Perspectives on the U.S. Debate. Kalamazoo, MI: W.E. Upjohn Institute for Employment Research.

Viceira, Luis M. (2007) Life cycle funds. In Annamaria Lusardi, John Campbell, and James Porterba (eds.), Overcoming the Saving Slump: How to Increase the Effectiveness of Financial Education and Saving Programs, Chap. 5. Chicago: University of Chicago Press.

Vissing-Jorgensen, Annette (2002) Towards an Explanation of Household Portfolio Choice Heterogeneity: Nonfinancial Income and Participation Cost Structures. NBER working paper 8884 .

\section{APPENDIX A: NUMERICAL ALGORITHM}

Our numerical algorithm follows Gomes et al. (2009). To reduce the number of state variables we normalize all variables by the permanent income component, $P_{t}$, and denote them by lower case letters. This reduces the state variables to $w_{t}^{\tau}, w_{t}^{r}, I_{t}, U_{t}$, and $t$.

The household decides to pay the fixed cost at age $t$ and compares the two value functions:

$$
v_{t}\left(w_{t}^{t}, w_{t}^{r}, U_{t}, I_{t}\right)=\max _{0,1}\left\{v_{t}\left(w_{t}^{t}, w_{t}^{r}, U_{t}, I_{t}=0\right), v_{t}\left(w_{t}^{t}, w_{t}^{r}, U_{t}, I_{t}=1\right)\right\}
$$


The value function solves

$$
v_{t}\left(w_{t}^{t}, w_{t}^{r}, U_{t}, I_{t}\right)=\left\{\max _{c_{t}, k_{t}, \alpha_{t}^{t}, \alpha_{t}^{r}} \frac{c_{t}^{1-\rho}}{1-\rho}+\beta E_{t}\left(\frac{P_{t+1}}{P_{t}}\right)^{1-\rho} p_{t} v_{t}\left(w_{t}^{t}, w_{t}^{r}, U_{t}, I_{t}\right)\right\},
$$

subject to the normalized constraints (1), (2), (3), (4), depending on the age and type of the individual account.

To solve the model we start from the last period and proceed backward. At any point in the state space we find the optimal choices using grid search. We apply tensor product splines to interpolate for points that do not lie on the grid. Numerical integrations are performed using Gaussian quadrature. To take account of the higher curvature of the value function, we follow Gomes et al. (2009) and use a grid with more points allocated to lower levels of wealth. To decide whether to pay the fixed stock market entry costs at time $t$, the household compares the two value functions associated with direct stock market participation, $I_{t}=1$, and no direct access to stock markets, $I_{t}=0$. We take the maximum of the two value functions and derive the policy functions for the current period. Using these policy functions, we update this period's value function and proceed with solving the previous period's maximization problem. We iterate until $t=1$.

\section{APPENDIX B: UTILITY COST CALCULATION}

To evaluate the welfare implications of different types of individual accounts, we calculate the utility costs of mandatory add-on and carve-out accounts relative to the benchmark scenario, which we assume to be the voluntary add-on account with endogenous $\alpha^{r}$. For each scenario, we calculate the constant consumption stream that makes the household as well off in terms of expected utility. Utility costs are calculated in terms of percentage deviations in certainty-equivalent consumption relative to the benchmark scenario.

Following Cocco et al. (2005), we compute expected lifetime utility for each model scenario as follows. We start from the expected discounted lifetime utility at the beginning of working life:

$$
V_{1}=E_{1} \sum_{t=1}^{T} \beta^{t-1}\left(\prod_{j=0}^{t-1} p_{j}\right) \frac{C_{t}^{1-\rho}}{1-\rho}
$$

From this expression we calculate the equivalent constant consumption stream $\bar{C}$ that makes the agent indifferent between this constant consumption and the consumption stream she would obtain optimally:

$$
V_{1}=E_{1} \sum_{t=1}^{T} \beta^{t-1}\left(\prod_{j=0}^{t-1} p_{j}\right) \frac{\bar{C}^{1-\rho}}{1-\rho}
$$

It follows that

$$
\bar{C}=\left[\frac{(1-\rho) V}{\sum_{t=1}^{T} \beta^{t-1}\left(\prod_{j=0}^{t-1} p_{j}\right)}\right]^{\frac{1}{1-\rho}}
$$


As an example, consider the welfare effects of mandatory add-on accounts. The utility cost in percentage deviation in certainty-equivalent consumption is given by

$$
\operatorname{Loss}^{\text {mandatory }}=\frac{\bar{C}^{\text {voluntary }}-\bar{C}^{\text {mandatory }}}{\bar{C}^{\text {mandatory }}} \times 100 .
$$

\section{APPENDIX C: THE SURVEY OF CONSUMER FINANCES DATA}

To compare our model results with the data, we use the 2001 and 2013 waves of the Survey of Consumer Finances (SCF) data. The SCF is the most comprehensive survey on households' assets, pensions, income, and demographic characteristics in the United States. It is a triennially repeated cross-sectional survey that is representative of the population of the United States. We construct wealth in the TA and in the TDA as well as nonfinancial income to compute wealth-to-income ratios.

Our (gross) income measure is the sum of wages and salaries, business/practice/farm income, rent and royalties, unemployment income, child support and alimony, food stamps and welfare income, social security or other pensions, annuities or other disability and retirement programs, and other income.

To calculate total wealth in the TA, we sum up savings and money market accounts, certificates of deposit, government mutual funds, other bond mutual funds, corporate bonds, saving bonds, tax-free bond mutual funds, combination of mutual funds, call and checking account balances, annuities, trusts, directly held stocks, and stock mutual funds. We subtract from that non-credit-card debt and nonresidential real estate debt (unsecured loans and loans secured by pensions). We define risky assets in the TA as the sum of stocks, stock mutual funds, and half of combination mutual funds, as well as annuities and trusts that are allocated to stocks. Negative values are dropped.

Total wealth in the TDA consists of IRA/KEOGH plans, bonds and stocks in other future pensions, and bonds and stocks in any account-type pension plan for which there is information on asset allocation. Risky assets in the TDA are the sum of all accounts invested (mainly) in stocks by the main respondent, his/her spouse, and other family members.

We calculate the risky portfolio share in the TA (TDA) as the ratio of risky assets to total TA (TDA) wealth per household and then take the mean over all households. We use the five implicates and sample weights for the statistics given in the tables. 